\title{
Toxicity of shoti (Indian arrowroot: Curcuma zedoaria) for rats and chicks
}

\author{
BY M. A. LATIF* AND T. R. MORRIS \\ Department of Agriculture, University of Reading, Reading RG6 $2 A T$ \\ AND A. H. MIAH,* D. HEWITT AND J. E. FORD \\ National Institute for Research in Dairying, Shinfield, Reading RG2 $9 A T$
}

(Received 23 June 1977 - Accepted 22 August 1977)

\begin{abstract}
1. A flour was prepared from rhizomes of shoti (Curcuma zedoaria) in such a way that most of the protein was retained. The crude protein (nitrogen $\times 6 \cdot 25$ ) content in this product was $155 \mathrm{~g} / \mathrm{kg}$, compared with approximately $10 \mathrm{~g} / \mathrm{kg}$ in commercial shoti flour.

2. The high-protein flour proved highly toxic to 5-week-old rats and caused $100 \%$ mortality within $6 \mathrm{~d}$ when given at $320 \mathrm{~g} / \mathrm{kg}$ diet.

3. Fresh rhizomes were minced and dried, and the resulting meal was given to weanling rats at $400 \mathrm{~g} / \mathrm{kg}$ diet. All the animals lost weight rapidly, and two of the five rats died within $4 \mathrm{~d}$.

4. This same shoti meal was given to $\mathrm{I}$-d-old chicks at 100 and $200 \mathrm{~g} / \mathrm{kg}$ diet. All the chicks survived the test period $(20 \mathrm{~d})$, but body-weight, food intake and efficiency of food conversion decreased with increase in the level of shoti meal in the diet.

5. The traditional method of preparing shoti involves prolonged washing in changes of water, which removes most of the protein and other water-soluble nutrients and, presumably, a toxic constituent. Further investigation is needed to identify the toxic principle, and to discover a less wasteful procedure for removing it.
\end{abstract}

Starch prepared from rhizomes of Curcuma zedoaria, commonly known as shoti, is extensively used as gruel to feed infants and invalids in many rural areas of Bangladesh, India, Ceylon, China and other South-East Asian countries. Shoti is a member of the ginger family of plants (Zingiberaceae) and grows in abundance in the forests of India and Asia and at roadsides and on fallow land. It is also cultivated in some areas as a root crop. Villagers collect the rhizomes, mince them and then soak them in water for several hours. The fibres and coarse particles are removed and the white residue is washed several times to remove the camphoraceous odour and the pungent bitter principles. During this washing process most of the protein is removed. The washed residue is dried and ground and used to prepare gruel for infants. It has been reported that the raw, unprocessed tubers of shoti plants are also eaten, after washing, by the poorer section of the rural community during times of acute scarcity of food, and that the tender buds are sometimes used in salads.

Shoti starch prepared commercially by the conventional method has only approximately Io $\mathrm{g}$ crude protein (nitrogen $\times 6.25$ ) and $800 \mathrm{~g}$ starch $/ \mathrm{kg}$. The dried whole rhizome contains IOO- $130 \mathrm{~g}$ crude protein with approximately $500 \mathrm{~g}$ starch $/ \mathrm{kg}$. The enormous quantities of shoti that grow naturally represent an under-exploited and potentially valuable source of food for humans and domestic animals. The initial aim in the present investigation was to conserve the protein in the preparation of a shoti meal, and to determine its nutritional quality in growth tests with chicks and rats.

Two experiments were done. For the first, shoti rhizomes were processed in the laboratory in such a way that the protein was largely retained in the flour. This material, shoti flour, was tested in growth assays with rats. For the second experiment, a shoti meal was made

\footnotetext{
* Present address: Faculty of Animal Husbandry, Bangladesh Agricultural University, Mymensingh, Bangladesh.
} 
by mincing, drying and grinding the rhizomes. This meal was used in growth tests with rats and chicks.

\section{EXPERIMENT AL}

\section{Preparation of shoti flour}

Shoti rhizomes from Bangladesh were washed, sorted, minced in a food mincer to a fine paste and diluted with water. The $\mathrm{pH}$ of the suspension was adjusted to 9.0 and it was allowed to stand for I0-I $5 \mathrm{~min}$. After thorough mixing, the suspension was filtered through cheese-cloth to remove suspended coarse particles. The $\mathrm{pH}$ of the filtrate was then adjusted to 4.5 to precipitate protein. The precipitation was completed by increasing the temperature to boiling point. Heating was then stopped and the mixture was left to stand for $1-2 h$ allowing the proteins and starch to settle. The supernatant fraction was removed and the residue was washed four times with cold water. The washed residue was then dried in an air oven at $55^{\circ}$. The procedure followed was essentially the same as that used by Pirie (1971) for the preparation of leaf protein or soya-bean protein concentrates. The crude protein content of the shoti flour thus prepared was found to be $155 \mathrm{~g} / \mathrm{kg}$.

\section{Preparation of shoti meal}

Shoti meal was prepared from two later consignments of rhizomes, also from Bangladesh. The rhizomes were minced and dried in a current of air at approximately $45^{\circ}$, and then ground in a hammer mill. Some of the rhizomes in one of the consignments were very slightly mouldy, and they were therefore peeled to remove all visible signs of the infection before being further processed.

The crude protein content of the dried meal was $132 \mathrm{~g} / \mathrm{kg}$.

\section{Biological tests}

Rats of the Hooded Norwegian strain were used in Expt I, 2 and 3.

Expt $\mathrm{I}$. Experiments were designed to determine $(a)$ the digestibility and biological value, and $(b)$ the protein efficiency ratio, of our preparation of shoti flour, using 3-week-old female weanling rats. The test diets contained 516 and $645 \mathrm{~g}$ shoti flour $/ \mathrm{kg}$, providing 80 and $\mathrm{I} 00 \mathrm{~g}$ protein $/ \mathrm{kg}$ respectively. In the event, all the rats given diets containing the shoti flour died within $5 \mathrm{~d}$. We know of no published work that would have led us to anticipate that our preparation would prove so highly toxic.

Expt 2. This experiment was designed to examine the toxicity of shoti flour by feeding graded levels to growing rats. Five rations, containing $0,16 \mathrm{I}, 322,484$ and $645 \mathrm{~g}$ shoti flour/ $\mathrm{kg}$, were prepared by mixing the appropriate quantities of the shoti-flour diet used in the protein efficiency ratio test with a conventional commercial rat diet. Five 5-week-old male rats were assigned at random to each of the shoti-flour diets while a control group of four rats was given the commercial diet without shoti flour. The diets were given fresh daily as a wet mash to individually caged rats.

Expt 3. In this experiment the shoti meal prepared from air-dried minced rhizomes was compared with maize starch and raw potato starch. The maize starch was included as a control treatment, and the raw potato starch as an example of an indigestible form of starch, since we had found in an earlier experiment that the faeces of rats given uncooked shoti flour contained many undigested starch grains. The test diets consisted of commercial rat diet alone and mixed with maize starch, raw potato starch or shoti meal in the proportions: commercial rat diet 600 , test supplement 400 . Five 4-week-old male rats were allocated at random to each test diet. The rats were individually caged and each animal was offered daily, as a wet mash, a weight of diet equal to one-tenth of its body-weight. Any food remaining uneaten after $24 \mathrm{~h}$ was collected, dried and weighed. Body-weights and food 
Table I. Composition and calculated analysis $(\mathrm{g} / \mathrm{kg})$ of experimental diets for chicks

\begin{tabular}{|c|c|c|c|}
\hline & & Shoti (Curcum & al* diet \\
\hline & $\begin{array}{l}\text { Maze-soya-oean } \\
\text { control diet }\end{array}$ & 100 & 200 \\
\hline Ingredients & & & \\
\hline Shoti meal & 0 & 100 & 200 \\
\hline Ground maize & 590 & 478 & 355 \\
\hline Soya-bean meal & 358 & 353 & 355 \\
\hline Maize oil & 15 & $32 \cdot I$ & $53 \cdot I$ \\
\hline Limestone flour & II & II & II \\
\hline Dicalcium phosphate & $17 \cdot 8$ & 17.5 & 17.3 \\
\hline Sodium chloride & $3 \cdot 7$ & $3 \cdot 7$ & 3.7 \\
\hline Vitamins and trace minerals $\dagger$ & $3 \cdot 0$ & $3 \cdot 0$ & $3 \cdot 0$ \\
\hline DL-methionine & $1 \cdot 5$ & $\mathrm{I} \cdot 7$ & $\mathrm{I} \cdot 9$ \\
\hline Calculated analysis & & & \\
\hline $\begin{array}{l}\text { Crude protein (nitrogen } x \\
6.25 \text { ) }\end{array}$ & $2 \mathrm{II}$ & 212 & 214 \\
\hline Energy $(\mathrm{kJ} \mathrm{ME} / \mathrm{g})$ & $12 \cdot 76$ & $12 \cdot 30$ & $12 \cdot 43$ \\
\hline Calcium & $10 \cdot 2$ & $10 \cdot 5$ & 10.9 \\
\hline Phosphorus & 4.9 & $5 \cdot 3$ & $5 \cdot 7$ \\
\hline Sodium & $\mathrm{I} \cdot 65$ & 1.66 & $\mathrm{I} \cdot 69$ \\
\hline Methionine & $4 \cdot 8$ & $4 \cdot 8$ & $4 \cdot 8$ \\
\hline Lysine & $11 \cdot 6$ & II $\cdot 2$ & II $\cdot I$ \\
\hline Crude fibre & $33 \cdot 3$ & $35 \cdot 6$ & $38 \cdot 0$ \\
\hline
\end{tabular}

consumption were recorded for $4 \mathrm{~d}$. All the rats, including those that died during this $4 \mathrm{~d}$ period, were dissected and inspected for gross pathological signs.

Expt 4. This experiment was done to determine whether the shoti meal used in Expt 3 was toxic to chicks. Because of the high mortality found in rats given high levels of shoti flour and meal, a preliminary test was conducted in which ten chicks were given for $14 \mathrm{~d}$ a diet containing $295 \mathrm{~g}$ shoti meal $/ \mathrm{kg}$. All the chicks survived the test period, but their growth rate was much below normal. This finding led to the use of lower levels (I00 and $200 \mathrm{~g} / \mathrm{kg}$ ) of the meal in Expt 4 .

Eighty-four Ross I cockerels (broiler chicks) were allocated at I-d-old to twelve compartments in two electric battery brooders using the top three tiers of the brooders. There were two compartments in each tier. Two diets, containing 100 and $200 \mathrm{~g}$ shoti meal $/ \mathrm{kg}$, were compared with the maize-soya-bean control diet (Table I) from 0-20 d. The diets were balanced for all major nutrients. Diets were allocated at random to the experimental units, using a randomized block design. The chicks were weighed as groups at I, 7, 14 and $20 \mathrm{~d}$ of age.

\section{Analytical}

A sample of shoti meal was analysed for proximate ingredients by standard methods (AOAC, 1975). When determining total $\mathbf{N}$ in the shoti meal, salicylic acid was added to the digestion mixture in the Kjeldahl flask. The amount of $\mathrm{N}$ found was corrected by subtracting nitrate-, nitrite- and ammonia-N, before multiplying by 6.25 to obtain a value for crude protein. The amino acid composition of the flour and of the meal were determined by column chromatography of the respective hydrolysates, using an amino acid analyser (model JLC-5AH; Jeolco Ltd, Tokyo, Japan). The hydrolysates were prepared by refluxing samples containing approximately Ig sample and $450 \mathrm{ml} 6 \mathrm{M}-\mathrm{HCl}$ for $24 \mathrm{~h}$ in an oil-bath at $110^{\circ}$, concentrating by rotary evaporation at $45^{\circ}$ and redissolving in $0.1 \mathrm{I}$ M-sodium citrate at 
Table 2. Composition $\left(\mathrm{g} / \mathrm{kg}\right.$ ) of shoti (Curcuma zedoaria) flour and shoti meal ${ }^{*}$

Dry matter
Ash
Total nitrogen
Nitrate- and nitrite-N
Ammonia-N
Crude protein $(\mathrm{N} \times 6 \cdot 25)$
True protein $\dagger$
Diethylether extract
Crude fibre
Reducing sugars
Starch
Amino acids
Lysine
Histidine
Arginine
Aspartic acid
Threonine
Serine
Glutamic acid
Proline
Glycine
Alanine
Cystine
Valine
Methionine
Isoleucine
Leucine
Tyrosine
Phenylalanine
Tryptophan
Tring

$\begin{array}{cc}\text { Shoti flour } & \text { Shoti meal } \\ - & 906 \\ - & 76 \\ 24 \cdot 8 & 21 \cdot 1 \\ - & 4 \cdot 6 \\ - & 2 \cdot 5 \\ 155 & 88 \\ - & 41 \\ - & 43 \\ - & 45 \\ - & 46 \\ - & 446\end{array}$

(g/kg crude protein)

$\begin{array}{rr}52 & 27 \\ 24 & 13 \\ 62 & 27 \\ 185 & 88 \\ 49 & 29 \\ 50 & 30 \\ 107 & 77 \\ 30 & 22 \\ 56 & 39 \\ 36 & 38 \\ 12 & 7 \\ 45 & 37 \\ 11 & 11 \\ 54 & 34 \\ 106 & 59 \\ 41 & 22 \\ 52 & 31 \\ 26 & -\end{array}$

* For details of preparation, see p. 58 .

$\dagger \mathrm{N} \times 6.25$ remaining after two extractions with trichloroacetic acid solution ( $100 \mathrm{ml} / \mathrm{l})$.

$\mathrm{pH} \mathrm{2.2.} \mathrm{Tryptophan} \mathrm{was} \mathrm{measured} \mathrm{microbiologically} \mathrm{by} \mathrm{the} \mathrm{method} \mathrm{of} \mathrm{Scott} \mathrm{(1976).} \mathrm{Samples}$ of the meal prepared from the mould-infected consignment of shoti (p. 58) were sent to the Public Analyst, Elgar Road, Reading, and to the Laboratory of the Ministry of Agriculture, Fisheries and Food, Shardlow Hall, Derby. They were analysed for aflatoxin, and for the possible presence of several other toxic compounds (p. 62).

\section{RESULTS}

Composition of shoti flour and meal. Table 2 shows the proximate composition of the shoti meal and the amino acid analysis of both of the test preparations. The $\mathrm{N}$ content in the flour was approximately $17 \%$ greater than that in the meal, but the true protein content was more than three times greater. The amino acids accounted for 0.96 of the $\mathrm{N}$ in the flour and 0.35 of that in the meal. Approximately 0.34 of the $\mathrm{N}$ in the meal was accounted for as ammonia, nitrate and nitrite. The metabolizable energy value of the meal was $12.4 \mathrm{MJ} / \mathrm{kg}$ (2960 kcal $/ \mathrm{kg}$ ), as calculated using the equation of Carpenter \& Clegg (1968).

\section{Rat experiments}

In Expt I all the rats that were given diets containing shoti flour died in the early stages of the trial. 
Table 3. Expt 2. Growth, food intake and survival of 5-week-old rats given diets containing different concentrations of shoti (Curcuma zedoaria) flour*

\begin{tabular}{|c|c|c|c|c|}
\hline No. of rats & $\begin{array}{l}\text { Concentration of } \\
\text { shoti flour }(\mathrm{g} / \mathrm{kg})\end{array}$ & $\begin{array}{c}\text { Mean wt change } \\
(\mathrm{g} / \mathrm{d})\end{array}$ & $\begin{array}{l}\text { Mean food } \\
\text { intake }(g)\end{array}$ & $\begin{array}{l}\text { Mean survival } \\
\text { time (d) }\end{array}$ \\
\hline $\begin{array}{l}5 \\
5\end{array}$ & $\begin{array}{l}645 \\
484\end{array}$ & $\begin{array}{l}\dagger \\
\dagger\end{array}$ & $\begin{array}{l}6.2 \\
8.6\end{array}$ & $\begin{array}{l}4 \\
3.8\end{array}$ \\
\hline 5 & 322 & $t$ & 13.0 & $4 \cdot 4$ \\
\hline 5 & $16 I$ & $-3 \cdot 2$ & $52 \cdot 5$ & All survived \\
\hline 4 & 0 & $7 \cdot 6$ & $32 \cdot 5$ & All survived \\
\hline
\end{tabular}

Table 4. Expt 3. Growth and food intake of weanling rats given a commercial rat diet, or diets containing $(\mathrm{g} / \mathrm{kg}) 400$ shoti (Curcuma zedoaria) meal ${ }^{*}$, maize starch or potato starch and 600 commercial rat diet

(Each value is a mean for five rats given the diets for $4 \mathrm{~d}$ )

\begin{tabular}{|c|c|c|c|}
\hline $\begin{array}{c}\text { Supplement to commercial } \\
\text { rat diet }\end{array}$ & $\begin{array}{c}\text { Mean wl change } \\
(\mathrm{g} / \mathrm{d})\end{array}$ & $\begin{array}{l}\text { Mean food } \\
\text { intake }(g / d)\end{array}$ & $\begin{array}{c}\text { Mortality } \\
\text { (no. of deaths) }\end{array}$ \\
\hline None & 0.80 & $6 \cdot 8$ & 0 \\
\hline Shoti meal & -5.05 & $1 \cdot 0$ & 2 \\
\hline Maize starch & -0.45 & $6 \cdot 4$ & 0 \\
\hline Potato starch & -0.85 & $6 \cdot I$ & 0 \\
\hline SEM (16 df) & 0.26 & - & - \\
\hline
\end{tabular}

In Expt 2, in which different levels of shoti flour were given in the diet, the rats receiving 322,484 and $645 \mathrm{~g}$ shoti flour $/ \mathrm{kg}$ diet all died within $6 \mathrm{~d}$ (Table 3). All those given shoti flour lost body-weight and food intake decreased with increasing level of shoti flour in the diet.

In Expt 3 the rats given commercial rat diet gained weight $(0.80 \mathrm{~g} / \mathrm{d})$ during the test period, whereas those given this diet mixed with maize starch or potato starch lost weight $(0.45$ and $0.85 \mathrm{~g} / \mathrm{d}$ respectively) and consumed slightly less food (Table 4$)$. The animals given the test diet containing shoti meal ate very little food and lost weight rapidly. Two rats died within the $4 \mathrm{~d}$ test period. Analysis of variance indicated that weight gain was reduced by the supplements $(P<0.00 \mathrm{I})$ and that weight loss with shoti meal was greater than with the starches $(P<0.001)$. There was no clear difference between the starches $(P>0.05)$.

After $4 \mathrm{~d}$, some of the rats that had been given shoti meal exhibited pathological symptoms. In four of the five rats the caecal contents were very hard. During the experiment, until body-weight had decreased to approximately $46 \mathrm{~g}$, the rats given the shoti meal consumed small quantities of their diet fairly continuously and excreted a few small hard faecal pellets. In one of the two dead rats the bladder contents were faintly pink in colour, suggesting haematuria. In one survivor and in both dead rats the stomach contents contained blood. No pathological signs were observed in the other two surviving rats of this group.

\section{Chick experiments}

The results of Expt 4 are presented in Table 5. Body-weight gain, food intake and food conversion efficiency of chicks decreased with increasing levels of shoti-root meal in diets; 
Table 5. Expt 4. Mean body-weight gain, food intake and food conversion efficiency of chicks given diets containing 0,100 and $200 \mathrm{~g}$ shoti (Curcuma zedoaria) meal $* / \mathrm{kg}_{\text {from }} 0-20 \mathrm{~d}$

\begin{tabular}{|c|c|c|c|}
\hline Diets & $\begin{array}{l}\text { Body-wt gain } \\
\qquad(\mathrm{g} / \mathrm{d})\end{array}$ & $\begin{array}{l}\text { Food intake } \\
\qquad(\mathrm{g} / \mathrm{d})\end{array}$ & $\begin{array}{l}\text { Food conversion } \\
\text { efficiency ( } \mathrm{g} \mathrm{wt} \\
\text { gain } / \mathrm{g} \text { food intake) }\end{array}$ \\
\hline $\begin{array}{l}\text { Maize-soya-bean (control) } \\
\text { Shoti meal }(\mathrm{g} / \mathrm{kg})\end{array}$ & 20.5 & $34 \cdot I$ & 0.602 \\
\hline $\begin{array}{l}100 \\
200\end{array}$ & $\begin{array}{l}14 \cdot 1 \\
10.5\end{array}$ & $\begin{array}{l}27 \cdot 3 \\
21 \cdot 1\end{array}$ & $\begin{array}{l}0.516 \\
0.498\end{array}$ \\
\hline $\operatorname{SEM}(6 \mathrm{df})$ & 0.61 & $\mathrm{r} \cdot 85$ & 0.0117 \\
\hline
\end{tabular}

the control chicks gained weight normally. No birds died during the experiment. Apart from the depression of growth, the chicks showed no symptoms of toxicity.

\section{Laboratory studies}

Tests on the shoti meal, conducted at the Ministry of Agriculture, Fisheries and Food's Laboratory at Derby, showed that it contained no detectable aflatoxin $B_{1} \quad B_{2} G_{1} G_{21}$ ochratoxin A, B or C, patulin, citrinin, zearalenone, sterigmatocystin, diacetoxy scirpenol, trichothecin or cyanoglycoside. But when chloroform extracts of shoti meal were tested with brine shrimp (Artemia salina), according to the method of Brown et al. (1968), 100\% mortality was found. Removal of the pigment from the chloroform extract gave a product that was not toxic. Commercial shoti starch, which is free from pigment, was also free from the component toxic to brine shrimp.

The tests undertaken by the Public Analyst, Reading, showed that there was no aflatoxin nor any cyanoglycoside present in the shoti meal.

\section{DISCUSSION}

The traditional methods of preparing shoti starch involved grinding and extensive washing of the rhizomes in water until the product appeared white. In the process most of the protein, water-soluble vitamins and, presumably, the toxic components are removed. Shoti flour prepared in the laboratory by heat precipitation at $\mathrm{pH} 4 \cdot 6$, however, remained faintly green in colour and had a slightly bitter taste. Its crude protein content was $155 \mathrm{~g} / \mathrm{kg}$ as compared with approximately $10 \mathrm{~g} / \mathrm{kg}$ in commercial shoti starch.

The amino acid composition indicated that shoti protein should be of reasonable quality, though it contained somewhat less lysine than soya-bean protein. It is potentially valuable as a source of protein for man and animals. However, it was clear that problems may arise when attempts are made to conserve this protein for feeding to animals. Shoti flour at $322 \mathrm{~g} / \mathrm{kg}$ and higher and shoti meal at $400 \mathrm{~g} / \mathrm{kg}$ resulted in deaths in rats, while with $\mathrm{I} 6 \mathrm{I} \mathrm{g}$ shoti flour $/ \mathrm{kg}$ there was weight loss. Part of the effect might have been due to the inclusion of the starch in the diet. In Expt 3 (Table 4) replacing some of the commercial rat diet with maize starch or potato starch did result in loss of body-weight, but the effect was probably due to the reduction of protein intake. Shoti meal had a more dramatic effect on bodyweight. Food intake recorded for the shoti meal diet was so low that simple starvation might have explained the loss of body-weight, but there appeared to be pathological complications as well. Shoti meal in the chick diets at 100 and $200 \mathrm{~g} / \mathrm{kg}$ caused a marked reduction in food intake and in food conversion efficiency.

It is clear from these findings that the potential value of shoti as a source of both starch 
and protein will be realized only if it can be made free of its toxic component(s) at reasonable commercial cost.

The rhizomes produce a $\mathrm{I}-2 \%$ yield of a light yellow-coloured essential oil on steam distillation. This oil contains $(\mathrm{g} / \mathrm{kg})$ pinene $\mathrm{I} 5$, camphene 35 , cineol 96 , camphor 42 , borneol I5, sesquiterpenes 100, sesquiterpene alcohols 480 and also several sesquiterpenols (Rao et al. 1928). The toxicity of chloroform extracts of shoti meal for brine shrimps may implicate these essential oils.

The authors gratefully acknowledge the assistance given by Mr A. Hacking, Agricultural Development Advisory Service, Ministry of Agriculture, Fisheries and Food, Shardlow Hall, Derby, and Mr P. Martin of the Laboratory of the Public Analyst, Reading.

\section{REFERENCES}

Association of Official Analytical Chemists (1975). Official analytical methods, 12th ed. Washington DC: Association of Official Analytical Chemists.

Brown, R. F., Wildman, J. D. \& Eppley, R. M. (1968). J. Ass. Off. Analyt. Chem. 51, 905.

Carpenter, K. J. \& Clegg, K. M. (1968). J. Sci. Fd Agric. 7, 45.

Pirie, N. W. (editor) (197I). In Leaf Protein: its Agronomy, Preparation, Quality and Use, p. 53. Oxford and Edinburgh: Blackwell Scientific Publications.

Rao, S. B., Shintree, V. P. \& Simonsen, J. L. (1928). J. Soc. Chem. Ind., Lond. 47, I7 I.

Scott, K. J. (1976). Proc. Nutr. Soc. 35, 44A. 